\title{
The Concept of Offer in Different Legal Systems
}

\author{
Rdhwan Shareef Salih, \\ Department of Law, Faculty of Law, Political Science and Management, Soran University, Kurdistan Region- \\ Iraq.
}

\begin{abstract}
One of the essential elements of contract in both civil law and common law systems is agreement or consent of the parties. An agreement is composed of two elements: offer and acceptance. For the agreement to be valid, it must be possible to show that one party made an offer, and the other party accepted this offer. Two questions arise regarding offer in civil law and common law systems, as follows: What is the difference between offer and other steps in the negotiation process in both civil law and common law systems? What is the difference between termination of offer in both civil law and common law systems? The main aim of the current study is to illustrate the concept of offer and termination of offer in both civil law (French, German, Iraqi, Swiss and China Civil Code) and common law systems (English). To achieve this aim, the study examines offer in civil law and common law systems, then distinguishes preliminary statements from the offer and finally, explains circumstances under which offer may be terminated in both civil law and common law systems.
\end{abstract}

Keywords: Contract, Offer, Preliminary Stages in the Negotiation Process, Civil Law Systems, Common Law

Systems, Termination of Offer.

DOI: $10.7176 / \mathrm{JLPG} / 101-16$

Publication date:September $30^{\text {th }} 2020$

\section{Introduction}

People enter into contracts day after day. Contracts are indispensable tools of business and other human interactions. A contract is an agreement between two or more parties giving rise to obligations that are enforced or recognised by law. However, if the law was not enforcing it, then it is not a legally binding contract. Iraqi Civil Code defines contract and states, "[a] contract is the unison of an offer made by a contracting party with the acceptance of another party in a manner which establishes the effect thereof in the object of the contract." $\mathrm{A}$ contract is also described under Article 1101 of the French Civil Code which stipulates that a contract "is an agreement by which one or several persons commit themselves to one or more others to give, to do, or not to do something". ${ }^{2}$ It is worthwhile to note that the rules governing contracts in countries exercising common law differ considerably from those of the civil law countries. Civil law has its origin in Roman law, as codified in the Corpus Iuris Civilis of Justinian. The main feature of civil law is that; it is contained civil codes. Most civil codes were adopted in the nineteenth and twentieth centuries. For instance, French Code Civil in 1804, Austrian Burgerliches Gesetzbuch, 1811, German Burgerliches Gesetzbuch, 1896, Swiss Zivilgesetzbuch, 1907. In civil law system, the main principles and rules are contained in codes and statutes, and the courts main task is to apply and interpret the law contained in a code. On the other hand, common law evolved in England since around the 11th century and was later adopted in the USA, Canada, Australia, New Zealand and other countries of the British Commonwealth. Therefore, the main distinction between civil law and common law systems is that the civil law system is a codified system, while the common law is not created by means of legislation; it is based mainly on case law. In common law system, the principle is that earlier judicial decisions, usually of the higher courts, should be followed in the subsequent similar cases, and that precedents should be respected. ${ }^{3}$

In both legal systems, to conclude a valid contract, a number of essential elements and requirements are necessary; while, there is a difference between common law and civil law systems, in terms of the elements and requirements of a contract. Even in common law, there are different views about the elements and requirements of a contract, but it should be stated that generally, in common law system, there are three main elements: agreement between the parties, contractual intention to be legally bound by that agreement, and consideration provided by each of

\footnotetext{
${ }^{1}$ Iraqi Civil Code No.40 0f 1951, Article 73.

${ }^{2}$ French Civil Code of 1804, Article 1101.

${ }^{3}$ C Pejovic, 'Civil Law and Common Law: Two Different Paths Leading to the Same Goal' (2001) 32 VUWLR, $817-841$.
} 
parties. ${ }^{1}$ In some cases, the parties must comply with certain formalities. ${ }^{2}$ Also, there are a number of requirements that conclude a valid contract which are legal capacity of the parties, legality (the purpose of a contract must not be to break the law or contrary to public policy); the agreement must be genuine and not be affected by factors such as mistake, misrepresentation, fraud, undue influence and duress. ${ }^{3}$ Also, to some extent, the elements of a contract between civil codes are different. For example, in Iraqi Civil Code, there are three main elements: mutual consent (offer and acceptance); object and cause (it must be possible and must not be illegal and contrary to public order and morals). ${ }^{4}$ According to Indian Contract Act, the essential elements of a valid contract can be summed up as: agreement; intention to create legal relationship; free and genuine consent; parties competent to contract; lawful consideration; lawful object; agreements not declared void or illegal; certainty of meaning, possibility of performance; necessary legal formalities. ${ }^{5}$ Moreover, pursuant to French Civil Code, there are four conditions and elements for the validity of a contract which are: the consent of the parties; the capacity to contract; a certain objet (object) which forms the subject matter of the commitment (it must still exist and be determined, possible and lawful); and finally a lawful case in the obligation. ${ }^{6}$ Consequently, it is clear that one of the main essential elements of contract in both civil law and common law systems is agreement or consent of the parties.

An agreement is composed of two elements: offer and acceptance, and for a contract to be valid it must be possible to show that one party made an offer, and the other party accepted this offer. An offer is a proposal or expression of willingness by one party to enter into a legally binding contract with another. Throughout the literature, there are a large number and variety of definitions for offer. For example, an offer is commonly defined as "a declaration of will made by a party or as a declaration addressed to one or more specific persons in which the declarant manifests his or her intent to be bound by a contract."7 Offer also is defined as "a proposal by one party to enter into a legally binding contract with another. ${ }^{8}$ Moreover, MacMillan and Stone define offer as "an expression of willingness to contract on certain terms. It must be made with the intention that it will become binding upon acceptance." Pursuant to Indian Contract Act an offer is synonymous with proposal and it defines proposal as " when one person signifies to another his willingness to do or to abstain from doing anything, with a view to obtaining the assent of that other to such act or abstinence, he is said to make a proposal." ${ }^{10}$ Prof. Dr. Ohly also defines an offer as a "proposal or promise by one party (offeror) to another party (offeree) to enter into a contract on a particular set of terms with the intention of being legally bound." 11 Therefore, the person making an offer is called the offeror, and the person to whom the offer is made is called the offeree.

The offer may be made expressly (by words), or implied from conduct and it may be made to a definite (single) person, to a specified group (class of persons) of persons or to the world at large, which means to the general public. An offer to a definite person can only be accepted by that person. An offer to a definite group can only be accepted by a member of that group. An offer to the world at large can be accepted by anyone, for example a reward poster for the return of a lost pet can be accepted by anyone. ${ }^{12}$

However, often people who wish to enter into contracts make statements preliminary to the offer. These preliminary statements are not offers and they must be distinguished from the offer in both civil law and common

1 Lawyers from Allen \& Overy, At a Glance Guide to Basic Principles of English Contract Law < http://www.a4id.org/wp-content/uploads/2016/10/A4ID-english-contract-law-at-a-glance.pdf> accessed 13 August 2020.

${ }^{2}$ C Elliott and F Quinn, Contract Law (7th edn Pearson Education Limited, Harlow 2009) 9.

${ }^{3}$ D Longchamps and BH Wright, Canadian Hospitality Law: Liabilities and Risks (3rd edn Nelson Education Limited, Toronto 2006) 61-63, available at < http://www.longchamps3e.nelson.com/instructor/03Ch03.pdf $>$ accessed 13 August 2020.

${ }^{4}$ Iraqi Civil Code No.40 of 1951, Articles 77, 126 and 130.

${ }^{5}$ Indian Contract Act 1872, Section 2 and 10.

${ }^{6}$ French Civil Code of 1804, Article 1108.

${ }^{7}$ F Ferrari, 'Formation of Contracts in South American Legal Systems' (1994) 16 Loy. L.A. Int'1 \& Comp. L. Rev $629-659$.

${ }^{8}$ T E Uher and P Davenport, Fundamentals of Building Contract Management $\left(2^{\text {nd }}\right.$ edn UNSW Press, Sydney $2009) 9$.

${ }^{9} \mathrm{C}$ MacMillan and R Stone, Elements of the Law of Contract (University of London International Programmes Publication Office, London 2012)15.

${ }^{10}$ Indian Contract Act 1872, Section (2)a.

${ }^{11}$ Dr. Ohly, Introduction to English Law < http://www.zivilrecht8.uni-bayreuth.de/de/download/DownloadArchiv/English_Law_WS0809/EL_2_2_LN.pdf> accessed 15August 2020.

${ }^{12}$ Lawyers from Allen \& Overy, loc. cit. 
law systems. Additionally, terminations of offers are deferent in both legal systems.

In the light of the above clarification, two questions arise regarding offer in civil law and common law systems, as follows:

1. What is the difference between offer and other steps in the negotiation process in both civil and common law systems?

2. What is the difference between termination of offers in both civil law and common law systems?

To answer the questions, this study would be divided into four main sections. The study is introduced in the first section. The second section will appraise the offer in common law system in detail, and it will distinguish preliminary statements from the offer and explain circumstances under which offer may be terminated in common law systems. The third section will examine the offer, preliminary stages in the negotiation process, and termination of offer in civil law system. The fourth section will conclude the study by highlighting the significant findings.

\section{Offer in Common Law System}

According to common law system an offer is an expression of willingness to contract on specified terms, made with the intention that it is to be binding once accepted by the person to whom it is addressed (Stover v Manchester City Council [1974] $]^{1}$. Therefore, the nature of an offer is encapsulated by two cases involving the same defendant, which was Manchester City Council. The Council decided to sell houses that it owned to sitting tenants. In two cases, the claimants entered into agreements with the Council. The Council then resolved not to sell housing unless it was contractually bound to do so. In these two cases the question arose as to whether or not the Council had entered into a contract. ${ }^{2}$

According to Storer v Manchester City Council [1974], Manchester City Council decided to sell council houses to tenants and told its town clerk to create a simple form to create quick agreements, which dispensed with the legal formalities. Mr Storer applied to buy his council house, and on 9 March 1971 the town clerk wrote to him stating 'I understand you wish to buy your council house and I enclose the Agreement for Sale. If you will sign the Agreement and return it to me, I will send you the Agreement signed on behalf of the Council, in exchange'. The Agreement for Sale had been completed with details including the purchase price, the amount of the mortgage and the monthly repayments, although the date the tenancy was to cease and the mortgage repayment begin had been left blank. On 20 March Mr Storer signed and returned the Agreement, but before the town clerk had signed the Agreement for the Council, the Council changed political control and discontinued sales unless contracts had already been exchanged. Mr Storer sought specific performance alleging a binding contract. The Court of Appeal held that:

A binding contract had been concluded. The Council's intention was to become contractually bound when Storer had signed the Agreement and returned it, particularly as there was definite language used in the correspondence and there was a clear offer and acceptance.

In contrast, however, in Gibson v Manchester City Council $[1979],{ }^{3}$ as indicated in Figure 1, the Council sent Gibson a document which asked him to make a formal invitation (letter) to buy and stated that the Council 'may be prepared to sell' the house to him. The letter stated: '. The Corporation may be prepared to sell the house to you at the purchase price of $£ 2,725 \ldots$ If you would like to make formal application to buy your Council house, please complete the enclosed application form...' Gibson signed the document and returned it. The House of Lords held that a contract had not been concluded because the Council had not made an offer capable of being accepted. Lord Diplock stated:

The words 'may be prepared to sell' are fatal... so is the invitation, not, be it noted, to accept the offer, but 'to make formal application to buy' on the enclosed application form.

It is... a letter setting out the financial terms on which it may be the council would be prepared to consider a sale and purchase in due course.

\footnotetext{
${ }^{1}$ Storer v Manchester City Council [1974] 3 ALL ER 824.

${ }^{2}$ MacMillan and Stone, loc. cit.

${ }^{3}$ Gibson v Manchester City Council [1979] UKHL 6, [1979] 1 WLR 294.
} 
It should be noted from the two cases that an important distinction between them is that, in Storer's case there was an agreement as to price, but in Gibson's case there was not and important terms still needed to be determined in it.

Figure 1. Gibson v Manchester City Council [1979]

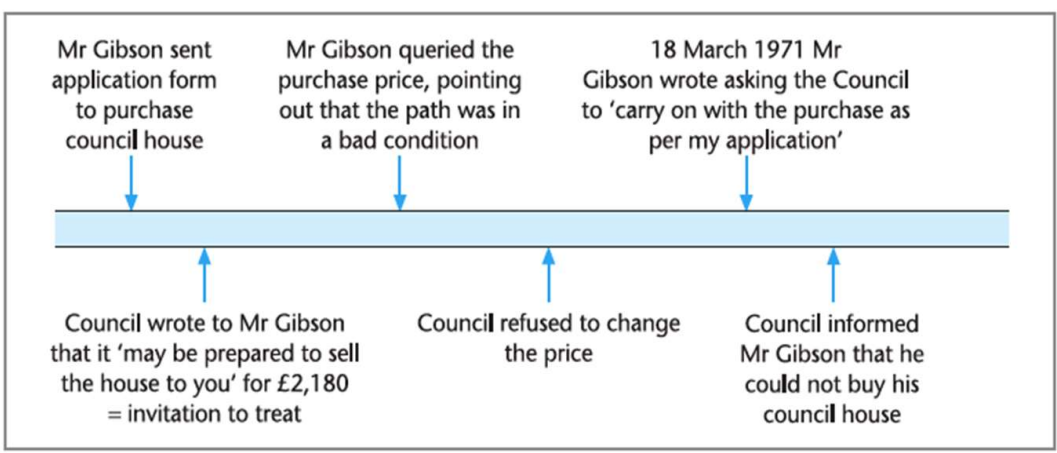

Source: Elliott and Quinn, op. cit., p. 15.

\subsection{Other Steps (Preliminary Stages) in the Negotiation Process}

It terms of offer, it should be said that, there must be no further negotiations or discussions required and it is very important to realise that not all communications will be offers. They will lack the requisite intention to be bound upon acceptance and there is a question that if they are not offers, what are they? To answer this question, an offer will be distinguished from other steps in the negotiation process. Other steps in the negotiation process might include declaration of intention and an invitation to offer that be explained, as follows:

\subsubsection{Declaration of Intention}

In this instance, one party states that he intends to do something. A declaration by a person that he intends to do a thing gives no right of action to another who suffers loss, because he does not carry his intention. This differs from an offer in that he is not stating that he will do something; such a declaration only means that an offer is to be made or invited in the future. For example, if an auctioneer announces the holding of an auction, it is not an offer but it is only a declaration that he intends to sell certain items and it is also an advertisement that an auction will take place. Thus, if the auction is cancelled or postponed at the last moment, any members of the public who came for the auction cannot claim their travel expenses from the auctioneer. ${ }^{1}$

According to Harris v Nickerson [1873] $]^{2}$ the defendant, an auctioneer, advertised in the London papers that certain brewing materials, plant, and office furniture would be sold by him at Bury St. Edmunds on a certain day and the two following days. The conditions were the usual; the first being, "the highest bidder to be the buyer." The plaintiff, a commission broker in London, went down to the sale. The plaintiff had a commission to purchase at the sale the "office furniture", which was advertised to be sold. The plaintiff went to Bury St. Edmunds and attended the auction, and purchased lots other than those described in the catalogue as "office furniture". The articles described as "office furniture" were not put up for sale. On the third day, on which the furniture was advertised for sale, all the lots of furniture were withdrawn. Following which the plaintiff brought an action against the defendant to recover for his loss of time and expenses. ${ }^{3}$ The decision by the court was unanimous and held that:

The advertisement was not an offer but a declaration of intention to sell the goods mentioned. The judges were of the opinion that the advertisement by the defendant was rather an invitation to treat and it could not be held as an offer, but merely a general part of the process of negotiation, which may or may not lead to an offer.

\footnotetext{
${ }^{1}$ MacMillan and Stone, loc. cit.

${ }^{2}$ Harris v Nickerson [1873] 1 LR 8 QB 286.

${ }^{3} \mathrm{~K}$ Goyal, Harris vs Nickerson By Jayant Sarkar from Lloyd Law College < http://educoncours.com/2017/08/18/harris-vs-nickerson-jayant-sarkar-lloyd-law-college/> accessed 17August 2020.
} 


\subsubsection{Invitations to offer}

In a preliminary stage of some kinds of transaction, one party invites the other to make an offer, which is called an invitation to offer. According to Gibson v Manchester City Council [1979], as mentioned earlier, negotiations to enter into a contract can amount to an invitation to offer but not an offer. In this case, the House of Lords ruled that the Council had not made an offer; the letter giving the purchase price was merely one step in the negotiations for a contract and amounted only to an invitation to offer. Its purpose was simply to invite the making of a 'formal application', amounting to an offer, from the tenant. ${ }^{1}$ Therefore, an invitation to offer is an indication of a willingness to conduct business. It is an invitation to make an offer or to commence negotiations. ${ }^{2}$ Common $^{2}$ examples of invitations to offer include advertisements or displays of goods on a shelf in a self-service store. Moreover, sometimes confusion may arise when what would appear, in the everyday sense of the word, to be an offer is held by the law to be only an invitation to offer. In these cases, courts have considered whether or not a communication was an offer or an invitation to offer in a wide variety of circumstances. This issue arises particularly in the following areas:

\section{A. Advertisements:}

A distinction is generally made between advertisements for a unilateral contract, and those for a bilateral contract* In terms of advertisements for unilateral contracts, it include advertisements such as the one in Carlill $v$ Carbolic Smoke Ball Co. [1893]. In that advertisements, as shown in Figure 2, it was stated that " $£ 100$ reward will be paid by the Carbolic Smoke Ball Company to any person who contracts the influenza after having used the ball three times daily for two weeks according to the printed directions supplied with each ball... $£ 1000$ is deposited with the Alliance Bank, showing our sincerity in the matter...", or advertisements that offering rewards for the return of lost property, or for information leading to the arrest or conviction of a criminal. These advertisements are usually considered as offers, on the grounds that the contract can normally be accepted without any need for further negotiations between the parties, and the person making the advertisement intends to be bound by it. ${ }^{4}$

Figure 2. The advertisement for Carbolic Smoke Balls

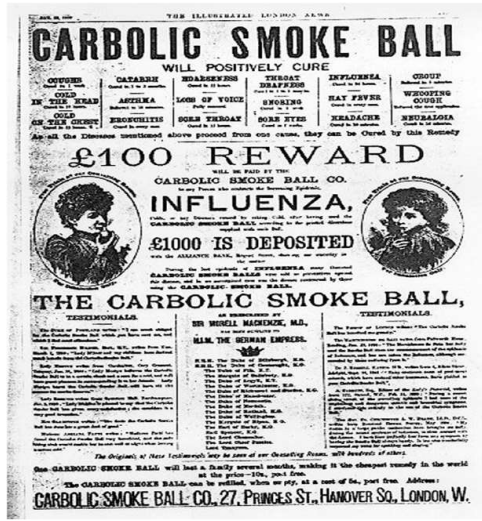

Source: C MacMillan and R Stone, Elements of the Law of Contract (1st edn University of London International Programmes Publication Office, London 2012) p.17.

Contrary, advertisements for a bilateral contract are the type of advertisements that advertise specified goods at a certain price. For example, those found at the back of newspapers and magazines. These advertisements are usually considered invitations to treat, on the basis that they may lead to further bargaining and potential buyers, for

\footnotetext{
${ }^{1}$ Elliott and Quinn, op. cit., 14.

${ }^{2}$ MacMillan and Stone, op. cit., 16.

* Most contracts are bilateral. This means that each party takes on an obligation, usually by promising the other something - for example, Ann promises to sell something and Ben to buy it. (Although contracts where there are mutual obligations are always called bilateral, there may in fact be more than two parties to such a contract.) By contrast, a unilateral contract arises where only one party assumes an obligation under the contract. Examples might be promising to give your mother $£ 50$ if she gives up smoking for a year, or to pay a $£ 100$ reward to anyone who finds your lost purse. See MacMillan and Stone, op. cit., 12.

${ }^{3}$ Carlill v Carbolic Smoke Ball Co. [1893] 1 QB 256.

${ }^{4}$ Elliott and Quinn, loc. cit.
} 
example might want to negotiate about the price, and that since stocks could run out, it would be unreasonable to expect the advertisers to sell to everybody who applied. ${ }^{1}$ According to Partridge $\boldsymbol{v}$ Crittenden [1968], ${ }^{2}$ an advertisement in a magazine, as shown in Figure 3, stated 'Bramblefinch cocks and hens, 25s each'. As the Bramblefinch was a protected species, the person who placed the advertisement was charged with unlawfully offering for sale a wild bird contrary to the Protection of Birds Act 1954, but his conviction was quashed on the grounds that the advertisement was not an offer but an invitation to treat.

Figure 3. Partridge Advertised 'Bramblefinch cocks, Bramblefinch hens, $25 \mathrm{~s}$ each'

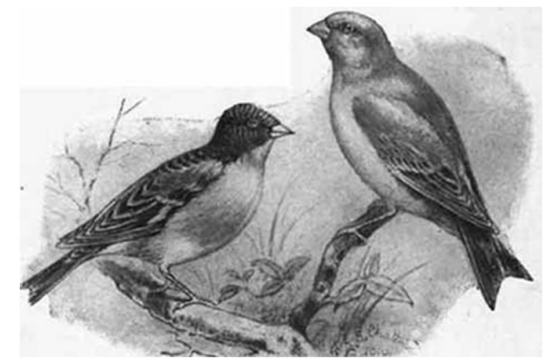

Source: MacMillan and Stone, op. cit., p. 16.

Additionally, in Grainger $\&$ Sons $\boldsymbol{v}$ Gough $[\mathbf{1 8 9 6}]^{\mathbf{3}}$ it was held that the circulation of a price-list by a wine merchant was not an offer to sell at those prices but merely an invitation to treat.

B. Display of Goods in Shops:

Price-marked goods on display on the shelves or in the windows of shops are generally not offers to sell goods at that price but they are invitations to treat. The customer makes an offer to purchase the goods. The trader will decide whether to accept the offer. For instance, in Fisher v Bell $[1961]^{4}$, certain legislation prohibited the sale or any 'offer to sell' certain types of knives with long blades. A shopkeeper had displayed flick knives in his shop window for sale. He was prosecuted by the police under the legislation for "having offer the knife for sale". On appeal, Lord Parker CJ stated that the display of an article with a price on it in a shop window was only an invitation to treat and not an offer, and the conviction was overturned. Therefore, the display of the knife in the shop window was not an offer to sell the knife but only an advertisement or an invitation to the public to inspect the knife. This was a highly technical argument but the court upheld it. Additionally, in Pharmaceutical Society v Boots [1953] $]^{5}$ boots were charged with an offence concerning the sale of certain medicines, which could only be sold by or under the supervision of a qualified pharmacist. Two customers in a self-service shop selected the medicines, which were price-marked, from the open shelves, and placed them in the shop's wire baskets. A pharmacist did not supervise the shelves, but a pharmacist had been instructed to supervise the transaction at the cash desk. The issue was therefore whether the sale had taken place at the shelves or at the cash desk. ${ }^{6}$ The court held that:

The goods on display on the shelf was an invitation to treat. When the customer took the goods off the shelf and handed them to the pharmacist at the cash register this was an offer by the customer to buy. At this point the pharmacist could query the choice and not proceed with the sale. The sale only took place when the pharmacist accepted the customer's offer by accepting the customer's money. Consequently, Boots Cash were not in breach of the law.

Therefore, pursuant to above cases, self-service in a shop is classified as an invitation to treat, and where goods are sold on a self-service basis, the customer makes an offer to buy when presenting the goods at the cash desk, and the shopkeeper may accept or reject that offer. In contrast, where a machine makes a display, the display will probably be an offer. According to Thornton v Shoe Lane Parking [1971] in which the court held that "the machine itself constituted the offer. The acceptance was by putting the money into the machine. The ticket was dispensed after the acceptance took place and therefore the clause was not incorporated into the contract".

\footnotetext{
${ }^{1}$ Ibid., 15.

2 Partridge v Crittenden [1968] 2 ALL ER 421.

${ }^{3}$ Grainger \& Sons v Gough [1896] AC 325.

${ }^{4}$ Fisher v Bell [1961] 1 QB 394.

${ }^{5}$ Pharmaceutical Society of Great Britain v Boots Cash Chemists (Southern) Ltd [1953] 1 QB 401.

${ }^{6}$ Elliott and Quinn, op. cit., 16.

${ }^{7}$ Thornton v Shoe Lane Parking [1971] 2 WLR 585 Court of Appeal.
} 
C. Request for Tenders

A request for tenders is an invitation to treat and each tender submitted is the offer unless the request specifies that it will accept the lowest or highest tender or other condition. If the request contains such a condition this will amount to an offer of a unilateral contract where acceptance takes place on performing the condition. ${ }^{1}$ In Spencer $v$ Harding ${ }^{2}$ the defendants advertised a sale by tender of the stock in trade belonging Eilbeck \& co. The advertisement specified where the goods could be viewed, the time of opening for tenders and that the goods must be paid for in cash. No reserve was stated. The claimant submitted the highest tender but the defendant refused to sell to him. The court stated that unless the advertisement specifies that the highest tender would be accepted there was no obligation to sell to the person submitting the highest tender. The advert amounted to an invitation to treat, the tender was an offer, the defendant could choose whether to accept the offer or not. ${ }^{3}$

Moreover, in Harvela Investments Ltd v Royal Trust Co of Canada Ltd [1985], Harvela and Sir Leonard were invited by Royal Trust to make sealed competitive bids for shares on certain terms and Royal Trust stated that it bound itself to no one except the highest bid. Royal Trust also stated that it would only accept a sealed and confidential single offer for the shares. Harvela lodged a bid of \$2,175,000 for the shares while Sir Leonard bid $\$ 2,100,000$ or $\$ 101,000$ in excess of Harvela's offer. The Royal Trust purported to accept the bid by the Sir Leonard of $\$ 2,276,000 .^{4}$ The court stated that the contract should have been awarded to the highest fixed bid, as the defendants were bound to accept the highest bid, the referential bid did not have a fixed amount attached to it and as such could not be accepted or even submitted. However, the invitation to treat may contain an implied undertaking to consider all conforming tenders, ${ }^{5}$ as in Blackpool and Fylde Aero Club Ltd v Blackpool Borough Council $[1990] .^{6}$

D. Auctions

An auctioneer's request for bids is an invitation to treat. The bid is an offer; when the auctioneer brings his hammer down he has accepted the offer. Where an auction takes place with reserve, each bid is an offer, which is then accepted by the auctioneer. In the case of auctions without a reserve price, the auctioneer enters into a collateral (or separate) contract. The nature of the collateral contract is that the auctioneer will accept the highest bid. In Barry $\boldsymbol{v}$ Davies [2000] ${ }^{7}$ a seller put up two engine analysers for sale by auction, with no reserve. The price of the machines would have been $£ 14,521$ each if they had been new. The claimant made a bid at the auction by $£ 200$ for each machine, and his bid was the highest bid. The auctioneer refused to sell the machines to the claimant for such a low price, despite the 'no reserve' sale. In this case Court of Appeal held that a collateral contract between the auctioneer and the highest bidder. The offer was made by the auctioneer to sell to the highest bidder, and this was accepted when the bid was made. ${ }^{8}$

\subsection{Termination of offers}

An offer, as illustrated in Figure 4, may be terminated under any of the following circumstances:

\footnotetext{
${ }^{1}$ Uk Web Hosting, Contractual Agreement - Offer and Acceptance $<\underline{\text { http://www.e-lawresources.co.uk/Offer- }}$ and-acceptance.php/index.php > accessed 20 August 2020.

${ }^{2}$ Spencer v Harding Law Rep. 5 C. P. 561.

${ }^{3}$ Uk Web Hosting, Spencer v Harding Law Rep. 5 C. P. $561<\underline{\text { http://www.e-lawresources.co.uk/Spencer-v- }}$ Harding.php $>$ accessed 20 August 2020.

${ }^{4}$ Doyles, Harvela Investment Ltd v royal Trust Co of Canada Ltd $<$ https://doylesconstructionlawyers.com/casewatch-list/harvela-investments-v-royal-trust-company-of-canada/> accessed 20 August 2020.

${ }^{5}$ MacMillan and Stone, loc. cit.

${ }^{6}$ Blackpool and Fylde Aero Club Ltd v Blackpool Borough Council [1990] 3 All ER 25, [1990] 1 WLR 1195.

${ }^{7}$ Barry v Davies [2000] 1 WLR 1962.

${ }^{8}$ E Mckendrick, Contract Law (12 ${ }^{\text {th }}$ edn Palgrave, London 2017) 32.
} 
Figure 4. Termination of an Offer

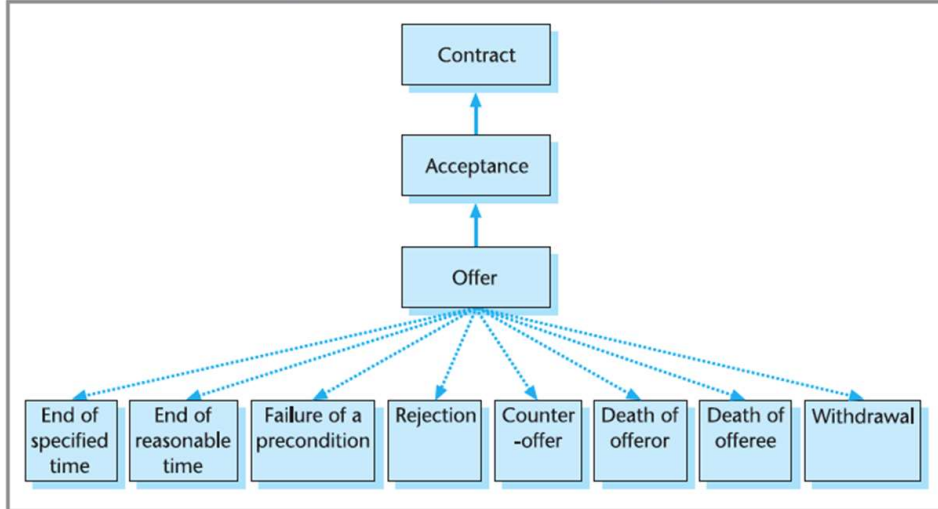

Source: Elliott and Quinn, op. cit., p.23.

\subsubsection{Death of Offeror or Offeree}

The position is not entirely clear, but it appears that if the offeree knows that the offeror has died, the offer will lapse and if the offeree is unaware of the offeror's death, it probably will not, see Bradbury v Morgan [1862]. For example, if (A) promises to sell her video recorder to (B) then dies soon after, and B writes to accept the offer, not knowing that A is dead, it seems that the people responsible for A's affairs after death would be obliged to sell the video recorder to $\mathrm{B}$, and $\mathrm{B}$ would be obliged to pay the price to the executors. It is noteworthy that where an offer requires personal performance by the offeror, for instance painting a picture, or appearing in a film, it will usually lapse on the offeror's death. In terms of the offeree's death, there is no English case on this point, but it seems probable that the offer lapses and cannot be accepted after the offeree's death by the offeree's representatives. ${ }^{1}$

\subsubsection{Lapse of Time}

An offer may be terminated by lapse of time. For example, an offer that is expressly states to last only for a specific period of time, after that period of time cannot be accepted. An offer specifies no time limit, will terminate after a reasonable lapse of time. ${ }^{2}$ What amounts to a reasonable time will depend on the nature of the contract and circumstances of each case. For example, offers to buy perishable goods, or a commodity whose price fluctuates daily, will lapse quite quickly. Offers to buy shares on the stock market may last only seconds. In Ramsgate Victoria Hotel $v$ Montefiore $[1866]^{3}$ the court upheld his argument that "five months was not a reasonable length of time for acceptance of an offer to buy shares, which are a commodity with a rapidly fluctuating price. Therefore the offer had lapsed before the company tried to accept it, and there was no contract between them." 4

\subsubsection{Revocation or Withdrawal of Offer}

The withdrawal of an offer is sometimes described as the revocation of an offer. ${ }^{*}$ An offeror may revoke an offer at any time before acceptance takes place. The Payne v Cave [1789] establishes the principle that an offer may be withdrawn at any time up until it is accepted. In Routledge v Grant $[1828]^{5}$ the defendant made a provisional offer to buy the plaintiff's house at a specified price, 'a definite answer to be given within six weeks from date'. It was stated that, regardless of this provision, the defendant still had the right to withdraw the offer at any moment before acceptance, even though the time limit had not expired. ${ }^{6}$ However to revoke an offer, the notice of revocation must be brought to the attention of the offeree. To bringing the withdrawal to the attention of the offeree, there is no

\footnotetext{
${ }^{1}$ Elliott and Quinn, op. cit., 19.

2 E McKendrick, Contract Law (4 ${ }^{\text {th }}$ edn Palgrave, London 2000) 52 and 53.

${ }^{3}$ Ramsgate Victoria Hotel v Montefiore [1866] LR 1 Ex 109.

${ }^{4}$ Elliott and Quinn, op. cit., 17.

* Common law does not distinguish between revocation and withdrawal. However, the Vienna Convention on Contracts for the International Sale of Goods (CISG) provides that an offer is presumed to be revocable at any time provided the revocation reaches the offeree before he has dispatched an acceptance (see article 15(2). After the offer reaches the offeree, the offeror may no longer withdraw the offer but may be entitled to revoke the offer in accordance with article 16.

${ }^{5}$ Routledge v Grant [1828] 130 ER 920.

${ }^{6}$ Ibid., 19.
} 
requirement that the offeror himself must to do it. ${ }^{1}$ Hence, it is not enough for offerors simply to change their mind about an offer. They must notify the offeree that it is being revoked. In Byrne \& Co v Leon Van Tienhoven $[1880]^{2}$, It was held that there was a binding contract, because revocation could only take effect on communication, but the acceptance by telegram took effect as soon as it was sent - in this case nine days before the revocation was received. By the time the second letter reached the plaintiffs, a contract had already been made. ${ }^{3}$

Furthermore, the revocation does not have to be communicated by the offeror; the communication can be made by some other reliable source. For example, according to Dickinson v Dodds [1876] ${ }^{4}$ the offer had already been revoked by the communication from the fourth man that the plaintiff heard about the sale of house through a fourth man. ${ }^{5}$ As mentioned, the withdrawal must be communicated to the offeree, but an exception to the rule exists when an offeree moves to a new address without notifying the offeror. In these circumstances, a withdrawal, which is delivered to the offeree's last known address, will be effective on delivery to that address. Also, where a withdrawal reaches the offeree, but the offeree simply fails to read it, the withdrawal probably still takes effect on reaching the offeree. This would be the position where a withdrawal by telex or fax reached the offeror's office during normal business hours, but was not actually seen or read by the offeree or by any of their staff until sometime afterwards $^{6}$, as held it in The Brimnes [1975]. ${ }^{7}$

\subsubsection{Counter Offer}

A counter-offer terminates the original offer. A counter offer is where an offeree responds to an offer by making an offer on different terms and the new offer destroys the original offer so that it is no longer open for the offeree to accept. In Hyde $\boldsymbol{v}$ Wrench [1840] the defendant offered to sell his farm for $£ 1,000$, and the plaintiff offered to buy it at $£ 950$, this is called making a counter-offer. The farm owner refused to sell at that price, and when the plaintiff later tried to accept the offer to buy at $£ 1,000$, it was held that this offer was no longer available; it had been terminated by the counter-offer. In this situation the offeror can make a new offer on exactly the same terms, but is not obliged to do so. ${ }^{8}$

\subsubsection{Rejection}

An offer terminates when the offeree rejects it. If A offers to sell B her car on Tuesday, and B says no, B cannot come back on Wednesday and insist on accepting the offer. Rejection may be effected by positive communication as well as by silence and it terminates the offer, as well as any further dealings between the parties must involve a fresh offer, ${ }^{9}$ as mentioned earlier in Hyde v Wrench [1840]. Besides, an offer that is stated to come to an end if a certain event occurs, cannot be accepted after that event has actually taken place. ${ }^{10}$ Moreover, some offers are made subject to certain conditions, and if such conditions are not in place, which is called Failure of a Precondition, the offer may terminate, for example, a person might offer to sell their bike for $£ 50$, if they manage to buy a car at the weekend, according to Financings Ltd v Stimson [1962]. ${ }^{11}$

\subsection{Communication of the Offer}

An offer must be communicated to the offeree before it can be accepted to be effective. Without knowledge of the offer, there can be no acceptance of the offer. There can be no 'meeting of the minds' if one mind is unaware of the other. In the other words, no one can accept offer without intending to do so, and he cannot intend to accept an offer of which he is not aware. ${ }^{12}$ For example, if A offers by advertisement a reward for 3,000 US\$ to anyone who returns his lost dog, and B, finding the dog, brings it to A without having heard of the offer of the reward, B is not entitled to the reward of 3,000 US\$. In the American case of Fitch v Snedaker [1868 $]^{13}$ the Police offered a reward

\footnotetext{
${ }^{1}$ McKendrick, op. cit., 51 and 52.

2 Byrne \& Co v Leon Van Tienhoven [1880] 5 CPD 344.

${ }^{3}$ Elliott and Quinn, op. cit., 19 and 20.

${ }^{4}$ Dickinson v Dodds [1876] 2 Ch. D.

${ }^{5}$ Ibid.

${ }^{6}$ Ibid.

${ }^{7}$ The Brimnes [1975] QB 929.

${ }^{8}$ Elliott and Quinn, op. cit., 18.

9 Longchamps and Wright, op. cit., 57.

${ }^{10}$ McKendrick, op. cit., 53.

${ }^{11}$ Elliott and Quinn, op. cit., 17 and 18.

${ }^{12}$ MacMillan and Stone, op. cit., 18.

${ }^{13}$ Fitch v Snedaker [1868] 38 NY 248
} 
for information leading to the arrest and conviction of a murderer. The Plaintiff, who was not aware of the offer of a reward, gave information to the police as a result of which the murderer was arrested. The Plaintiff was then informed of the reward and he claimed it. The Court held that he was not entitled to the reward because he had not been aware of the offer when he gave the information. The better view is thought to be expressed in the Australian case of $\boldsymbol{R} \boldsymbol{v}$ Clark [1927] $^{1}$, there cannot be assent without knowledge of the offer; and ignorance of the offer is the same thing whether it is due to never hearing of it or forgetting it after hearing.

\section{Offer in Civil Law System}

The concepts of offer and acceptance in civil law system are not fundamentally different from those in common law, although the effects may be different. In this section of the study, the French, German, Iraqi, Swiss and China Civil Code will be concentrated with regards to offer, as follows:

\subsection{French Civil Code}

French Civil Code also called Napoleonic Code or French Code Napoleon, is enacted on 21st March 1804 and still extant with amendments and contains 2534 articles. It was the main influence on the 19th-century civil codes of most countries. In terms of obligations, the law establishes the traditional Roman-law categories of contract, quasicontract, delict, and quasi-delict. Freedom to contract is not spelled out explicitly but is an underlying principle in many provisions. ${ }^{2}$ There was no specific article in the French Civil Code of 1804 that requires the existence of an offer and an acceptance. It only stipulates that four conditions are essential for the validity of a contract: the consent of the party who binds himself, his capacity to contract, a certain object which forms the subject-matter of the contract, and a lawful cause in the obligation. ${ }^{3}$ However, some parts of the French Civil Code have been modernized to keep pace with changing times, the codified articles on contract law had remained untouched since 1804. ${ }^{4}$ Recently, reform and modernization of contract law in French has taken place. The section of the Civil Code on the law of contract was amended in 2016. The amendment was issued by the Order ${ }^{*}$ No. 2016-131 of 10 February 2016. On 1 October 2016, the order modifying the French Civil Code provisions on contract law and the general regime and proof of obligations, entered into force. The order codified principles, which have emerged from the case law of the French courts but also created a number of new rules applicable to pre-contractual and contractual relationships. ${ }^{5}$

The French Civil Code Reform regulates formation of contracts in details, especially the offer and acceptance under sub-section 2 of section 1, which is called Conclusion of Contracts. The French Civil Code mentions consent but does not define it. However, the reform under new Article 1113 provides that "[a] contract is formed by the meeting of an offer and an acceptance by which the parties demonstrate their will to be bound." 6 The reform also defines and illustrates the offer and invitation to enter into negotiations, which stipulates, "[a]n offer, whether made to a particular person or to persons generally, contains the essential elements of the envisaged contract, and expresses the will of the offeror to be bound in case of acceptance. Failing this, there is only an invitation to enter into negotiations." $\mathrm{New}$ Articles 1115 and 1116 deals with withdrawing the offer, which state "[a]n offer may be withdrawn freely as long as it has not reached the person to whom it was addressed. An offer may not be withdrawn before the expiry of any period fixed by the offeror or, if no such period has been fixed, the end of a reasonable period. The withdrawal of an offer in contravention of this prohibition prevents the contract being concluded. The person who thus withdraws an offer incurs extra-contractual liability under the conditions set out by the general

\footnotetext{
${ }^{1}$ R v Clarke [1927], 40 CLR 227.

${ }^{2}$ The Editors of Encyclopædia Britannica, 'Napoleonic Code' $<$ https://www.britannica.com/topic/NapoleonicCode $>$ accessed 25 August 2020.

${ }^{3}$ French Civil Code of 1804, Article 1108.

4 S Rowan, 'The New French Law of Contract' International \& Comparative Law Quarterly (2017) < http://eprints.lse.ac.uk/75815/1/Rowan New\%20French\%20law 2017.pdf $>$ accessed 25 August 2020.

* Ordonnance No. 2016-131 of 10 February 2016

${ }^{5}$ Norton Rose Fulbright, Reform of the French Civil Code on contract law and the general regime and proof of obligations $<$ http://www.nortonrosefulbright.com/knowledge/publications/143164/reform-of-the-french-civilcode-on-contract-law-and-the-general-regime-and-proof-of-obligations\#autofootnote $2>$ accessed 25 August 2020.

${ }^{6}$ French Civil Code of 1804 (Amendment), Article 1113.

${ }^{7}$ French Civil Code of 1804 (Amendment), Article 1114.
} 
law, and has no obligation to compensate the loss of profits which were expected from the contract."1 Therefore, if the offer is withdrawn before the end of the period, or in violation of such rule but prior to acceptance prevent the conclusion of the contract; damages may be obtained, however these damages cannot compensate the loss of the benefits that were expected from the contract (as for sudden breach of negotiation).

The reform also provides several situations in which the offer is invalid. It states, "[a]n offer lapses on the expiry of the period fixed by the offeror or, if no period is fixed, at the end of a reasonable period. It also lapses in the case of the incapacity or death of the offeror." "This is a significant difference with current case law which, up to now, ruled that the offer did not disappear with the death of the offeror as long as it expressly contained a duration. ${ }^{3}$ Pursuant to the new code, an acceptance that does not conform to the offer, has no effect, apart from constituting a new offer. ${ }^{4}$ Also, silence does not count as acceptance, except where so provided by legislation, usage, business dealings or other particular circumstances, ${ }^{5}$ as well as a contract is concluded as soon as the acceptance reaches the offeror. It is deemed to be concluded at the place where the acceptance has arrived. ${ }^{6}$

In terms of unilateral promises, the new Article 1124 of the French Civil Code defines the unilateral promise by a contract in which one party (who is called the promisor) grants another party (who is called the beneficiary) a right to have the option to conclude a contract whose essential elements are determined, and for the formation of which only the consent of the beneficiary is missing. It also holds that revocation of the promise during the period allowed to the beneficiary to exercise the option does not prevent the formation of the contract, which was promised, as well as a contract concluded in breach of a unilateral promise with a third party who knew of its existence, is a nullity. ${ }^{7}$

Moreover, the reform of French Civil Code regulates contracts made by electronic means in details. It provides that, "[e]lectronic means may be used to make available contractual stipulations or information about property or services." A person who makes a proposal by electronic means for the supply of property or services, in a business or professional capacity must make available the applicable contractual stipulations in a way that permits their storage and reproduction. The offeror remains bound by its offer as long as it is made accessible by him by electronic means. An offer must set out in addition:

1. The different steps that must be followed to conclude the contract by electronic means;

2.The technical means by which the person to whom the offer is addressed, before the conclusion of the contract, may identify any errors in the data entry, and correct them;

3.The languages offered for the conclusion of the contract, which must include the French language;

4.Where appropriate, the ways in which the party issuing the offer is to file it, and the conditions for access to the filed contract;

5.The means of consulting electronically any business, professional or commercial rules to which the party issuing the offer intends (as the case may be) to be bound. ${ }^{9}$

Finally, it should be said that, pursuant to the reform of French Civil Code, for the validity of a contract the following are essential: the consent of the parties; their capacity to contract; content which is lawful and certain. ${ }^{10}$

\footnotetext{
${ }^{1}$ French Civil Code of 1804 (Amendment), Article 1115 and 1116.

${ }^{2}$ French Civil Code of 1804(Amendment), Article 1117.

${ }^{3} \mathrm{C}$ Cauuet and $\mathrm{G}$ Dubos, The reform of the French civil code and of contract law: consent to the contract $<$ http://www.loyerabello.fr/en/the-reform-of-the-french-civil-code-and-of-contract-law-consent-to-the-contract/> accessed 27August 2020.

${ }^{4}$ See French Civil Code of 1804 (Amendment), Article 1118.

${ }^{5}$ French Civil Code of 1804(Amendment), Article 1120.

${ }^{6}$ French Civil Code of 1804(Amendment), Article 1121.

${ }^{7}$ French Civil Code of 1804(Amendment), Article 1124.

${ }^{8}$ French Civil Code of 1804(Amendment), Article 1125.

${ }^{9}$ French Civil Code of 1804 (Amendment), Article 1127(1).

${ }^{10}$ French Civil Code of 1804 (Amendment), Article 1128.
} 


\subsection{German Civil Code ${ }^{1}$}

In German, contract law was codified in 1900 in the Bürgerliches Gesetzbuch (BGB) ${ }^{2}$. The object of the codification was the elaboration of the law which had been carried out very actively by German legal doctrine, during the preceding two centuries; legal scholars had devoted considerable energy to classifying and systemising primarily Roman law. The BGB thus codified the result of the scientific ideals of the XVIII and XIX centuries: rules were expressed on the highest possible level of abstraction, whereby the internal consistency of the system was the ultimate aim to reach. In addition to the ideal of scientific abstraction and consistency, the BGB was inspired by the ideal of liberalism, according to which each individual should be permitted to regulate its own interests as he deems fit and should be expected to take the responsibility therefor. ${ }^{3}$ Generally, German law has its roots in the Roman law tradition of the 19th Century. In addition, it is influenced by the French Civil Code ("Code Napoléon" of 1804) and many countries law are based upon German Civil Law, such as Italian law, Norwegian law and most South American Legal Systems Law. Therefore, it may be useful to explain its rules, in terms of contract formation, especially offer, as follows:

Pursuant to German Civil Code (BGB), any person who offers to another to enter into a contract is bound by the offer, unless he has excluded being bound by it. ${ }^{4}$ Therefore, an offer has binding character and cannot be revoked after being given. German Civil Code mentions a number of offer termination circumstances. For example, section 146 entitled 'Expiry of an Offer' stipulates that "an offer expires if a refusal is made to the offeror, or if no acceptance is made to this person in good time in accordance with sections 147 to $149 . " 5$ The code also states that "an offer made to a person who is present may only be accepted immediately. This also applies to an offer made by one person to another using a telephone or another technical facility." However, regarding an absent person, it holds that "an offer made to a person who is absent may be accepted only until the time when the offeror may expect to receive the answer under ordinary circumstances." ${ }^{\prime 6}$ Moreover, in terms of the determined period for acceptance, the code states, "if the offeror has determined a period of time for the acceptance of an offer, the acceptance may only take place within this period."7 Hence, depending on the offer's content, the offeree is bound by the offer for the period specified therein, or if this period is not specified, then for a reasonable period. The offer will be considered as revoked, if it was not accepted, or it was not accepted within specified period.

In terms of the death or incapacity to contract of the offeror, the code states that "the coming into existence of the contract is not prevented by the offeror dying or losing capacity to contract before acceptance, unless a different intention of the offeror is to be presumed." 8

The German Code also regulates promise of a reward (offer of reward) in details. Under the code, the offer of a reward made to anyone who performs a particular act is deemed to be accepted and is binding on the offeror when the act is performed, even if the person who performs the act does not know of the offer, unless, in cases which admit of it, the offer was previously revoked expressly and adequately by the offeror. The code provides these rule and as well as promise of a reward revocation in sections 657 and 658 as follows:

Anyone offering by means of public announcement a reward for undertaking an act, including without limitation for producing an outcome, is obliged to pay the reward to the person who has undertaken the act, even if that person did not act with a view to the promise of a reward. ${ }^{9}$

Additionally,

(1) The promise of a reward may be revoked until the act is undertaken. Revocation is only effective if it is announced in the same way as the promise of a reward was or if it occurs by means of a special announcement.

\footnotetext{
${ }^{1}$ Civil Code in the version promulgated on 2 January 2002 (Federal Law Gazette [Bundesgesetzblatt] I page 42, 2909; 2003 I page 738), last amended by Article 4 para. 5 of the Act of 1 October 2013 (Federal Law Gazette I page 3719 ).

${ }^{2}$ German Civil Code.

${ }^{3}$ G CMoss, 'International Contracts between Common Law and Civil Law: Is Non-state Law to Be Preferred? The Difficulty of Interpreting Legal Standards Such as Good Faith' (2007) 7(1) Global Jurist 1-38.

${ }^{4}$ German Civil Code (BGB) of 1896, Section 145.

${ }^{5}$ German Civil Code (BGB) of 1896, Section 146.

${ }^{6}$ German Civil Code (BGB) of 1896, Section 147 (1and 2).

${ }^{7}$ German Civil Code (BGB) of 1896, Section 148.

${ }^{8}$ German Civil Code (BGB) of 1896, Section 153.

${ }^{9}$ German Civil Code (BGB) of 1896, Section 657.
} 
(2) Revocability may be waived in the promise of a reward; in cases of doubt, a waiver may be seen in the setting of a period of time for undertaking the act. ${ }^{1}$

In terms of undertaking the act more than once and collaboration by more than one person, the German Code states:

(1) If an act for which a reward has been promised is undertaken more than once, then the reward is due to the person who undertook the act first.

(2) If the act has been undertaken simultaneously by more than one person, then each is entitled to an equal portion of the reward. Where the reward cannot be shared due to its quality, or if, according to the terms of the promise of a reward, only one person is to be given the reward, then the matter is decided by drawing lots. ${ }^{2}$

And

(1) If more than one person has contributed to an outcome for which the reward is promised, then the person promising the reward must apportion the reward at his reasonably exercised discretion, taking into account the contribution of each one to the outcome. The apportionment is not mandatory if it is evidently inequitable; in such a case the matter is decided by court decision.

(2) If the apportionment by the person promising the reward is not recognised as binding by one of those concerned, then the person promising the reward is entitled to refuse fulfilment until those concerned have settled the dispute on their entitlement among themselves; each of them may demand that the reward is deposited for all of them.

(3) The provision of section 659 (2) sentence 2 applies. $^{3}$

\subsection{Iraqi Civil Code}

Iraqi Civil Code No.40 was issued in 1951 and has been amended several times. In contrary to the law of much countries of civil law system, the Iraqi Civil Code regulates both offer and acceptance together, in a number of articles with respect of existence of consent. For example, the law provides that offer and acceptance are every two expressions (words) used customarily for the creation of a contract; and which expression is made first is an offer and the second is the acceptance. ${ }^{4}$ However, it is not true to say the first expression always is offer, it may be invitation to offer. Moreover, pursuant to the law, offer and acceptance will be in the past tense and may be in the future tense or in the form of an order where immediate execution performance is intended. ${ }^{5}$ Article 78 of the law also deals with future tense that is called promise by this article. The article holds that a future tense that has the meaning of only a promise and will be considered as a binding promise where the same was the intention of the contracting parties. ${ }^{6}$

Article 79 of the law states that "the offer and acceptance may be oral they may be by correspondence and by a sign which is in common usage even when it is not from a dumb person as well as by actual exchange denoting mutual acceptance and by any other method (way) the circumstances of which leave no doubt as to indicate mutual acceptance."7 The Iraqi Civil Law also distinguishes the offer from the invitation to offer as a number of country civil law and common law systems, but not very successfully. Contrary to the common law, Iraqi Civil Law states that the display of goods with a price shown on them is deemed to be an offer but publishing, advertising, and listing prices of current dealings and every other statement concerning offers or calls addressed to the public or to individuals shall not be deemed in case of doubt to be an offer but will be deemed an invitation to negotiate. ${ }^{8}$

Additionally, the law regulates silence. It stipulates that no statement will be attributed to a silent person, but silence will be deemed to be an acceptance in the course of need for expression or where there are previous dealings between the contracting parties and the offer was related to said dealings or where the offer proved to be to the benefit of the person to whom it was addressed, similarly the silence of a purchaser after having received (taken

\footnotetext{
${ }^{1}$ German Civil Code (BGB) of 1896, Section 658 (1 and 2)

${ }^{2}$ German Civil Code (BGB) of 1896, Section 659 (1 and 2)

${ }^{3}$ German Civil Code (BGB) of 1896, Section 660 (1-3)

${ }^{4}$ Iraqi Civil Code No.40 of 1951(Amendment), Article 77 (1).

${ }^{5}$ Iraqi Civil Code No.40 0f 1951(Amendment), Article 77 (2).

${ }^{6}$ Iraqi Civil Code No.40 0f 1951(Amendment), Article 78.

${ }^{7}$ Iraqi Civil Code No.40 0f 1951(Amendment), Article 79.

${ }^{8}$ Iraqi Civil Code No.40 0f 1951(Amendment), Article 80 (1 and2).
} 
delivery of) the goods purchased will be an acceptance of the conditions set down in the list of prices. ${ }^{1}$

Pursuant to the law, the contracting parties have an option after the offer until the end of the session, so where the offeror has withdrawn his offer, after offering and before the acceptance or where either contracting party utters saying (statement) or makes an act (gesture) which indicates rejection, the offer will be void and any acceptance uttered thereafter shall be disregarded. ${ }^{2}$ Therefore, according to the above statement, the Iraqi Civil Code mentions a number of offer termination circumstances, which are:

1. Withdrawal of offer by offeror before the acceptance.

2. Rejecting of the offer by saying and acting of either contracting party.

Articles 83 to 85 provides another circumstances of offer termination as follow,

3. Repetition of the offer: Repetition of the offer before the acceptance nullifies the first (offer) and the second offer will have effect. ${ }^{3}$

4. End of special time: The offeror who has set a time limit for his offer will be bound by his offer until such time limit expires, ${ }^{4}$ it means when the limited time be expired the offer will be terminate.

5. The acceptance not conforming to the offer: according to the article 85 , a contract to be concluded the acceptance by the other party must conform to the offer made. So, if there is no conforming, the offer will be terminate. ${ }^{5}$

The Iraqi civil law also regulates offer in auctions. According to the law, in auction any bid is vitiated by a higher bid even when the latter is void or by closing the bidding (auction) before it has been awarded to any person without in all of the foregoing prejudice to the provisions of the other laws. ${ }^{6}$

In terms of a preliminary agreement for future contract, the law states, a preliminary agreement pursuant to which both parties or either party undertake(s) to execute in future a certain specified contract shall not be valid unless the essential matters of and the time limit for execution of the contract to be executed have been stipulated. If the law has prescribed a certain form for the contract such form shall also be observed in the preliminary agreement, which contains a promise to execute this contract. ${ }^{7}$

\subsection{Contract Law of the People's Republic of China}

The Contract Law of China was issued in 1999. The law regulates the offer in a numbers of articles as follows: Firstly, the law states that an offer "is a party's manifestation of intention to enter into a contract with the other party, which shall comply with the following:

(i) Its terms are specific and definite;

(ii) It indicates that upon acceptance by the offeree, the offeror will be bound thereby."

As the common law system, the offer has been distinguished from the invitation to offer under the Contract Law of China. Pursuant to the Article 15, the Contract Law cites a number of circumstances, as invitations of offer not offers, which provides that "[a]n invitation to offer is a party's manifestation of intention to invite the other party to make an offer thereto. A delivered price list, announcement of auction, call for tender, prospectus, or commercial advertisement, etc. is an invitation to offer. A commercial advertisement is deemed an offer if its contents meet the requirements of an offer." 9

Under the Chinese Law, when an offer reaches the offeree it becomes effective. In respect of concluding a contract by the exchange of electronic messages, the law stipulates that if the recipient of an electronic message has designated a specific system to receive it, the time when the electronic message enters into such specific system is deemed the time of arrival; if there is no such specific system, the time when the electronic message first enters into any of the recipient's systems is deemed the time of arrival. ${ }^{10}$

\footnotetext{
${ }^{1}$ Iraqi Civil Code No.40 0f 1951(Amendment), Article 81.

${ }^{2}$ Iraqi Civil Code No.40 of 1951(Amendment), Article 82.

${ }^{3}$ Iraqi Civil Code No.40 of 1951(Amendment), Article 83.

${ }^{4}$ Iraqi Civil Code No.40 0f 1951(Amendment), Article 84

${ }^{5}$ Iraqi Civil Code No.40 0f 1951(Amendment), Article 84.

${ }^{6}$ Iraqi Civil Code No.40 0f 1951(Amendment), Article 89.

${ }^{7}$ Iraqi Civil Code No.40 0f 1951(Amendment), Article 91(1 and 2).

${ }^{8}$ Contract Law of the People's Republic of China of 1999, Article 14.

${ }^{9}$ Contract Law of the People's Republic of China of 1999, Article 15.

${ }^{10}$ Contract Law of the People's Republic of China of 1999, Article 16.
} 
The Contract Law of the People's Republic of China regulates 'withdrawal of offer' and 'revocation' in deferent articles. It states that an offer may be withdrawn or revoked. It also states that the notice of withdrawal shall reach the offeree before or at the same time as the offer, but the notice of revocation shall reach the offeree before it has dispatched a notice of acceptance. ${ }^{1}$

The law provides that in some circumstances an offer may not be revoked, these circumstances are as bellows:

(i) if it expressly indicates, whether by stating a fixed time for acceptance or otherwise, that it is irrevocable;

(ii) if the offeree has reason to regard the offer as irrevocable, and has undertaken preparation for performance. $^{2}$

Article 20 of the law cites a number of circumstances as an extinguishment of offer, which are:

(i) The notice of rejection reaches the offeror;

(ii) The offeror lawfully revokes the offer;

(iii) The offeree fails to dispatch its acceptance at the end of the period for acceptance;

(iv) The offeree makes a material change to the terms of the offer. ${ }^{3}$

Moreover, according to the Chinese Contract Law, an acceptance shall reach the offeror within the period prescribed in the offer. If there is no such period for, the acceptance shall reach the offeror as follows:

(i) Where the offer is made orally, the acceptance shall be dispatched immediately, unless otherwise agreed by the parties;

(ii) Where the offer is made in a non-oral manner, the acceptance shall reach the offeror within a reasonable time. $^{4}$

Finally, pursuant to the law, if an offer is made by a letter or a telegram, the period for acceptance starts on the date shown on the letter or the date on which the telegram is handed in for dispatch. The period starts on the posting date stamped on the envelope, if there is no specify date. Also, the period for acceptance starts once the offer reaches the offeree, if the offer is made through an immediate communication device such as telephone or facsimile, etc. ${ }^{5}$

\subsection{Swiss Civil Code}

The Swiss Civil Code was issued in 1907, which does not regulate the offer in details. However, it states that the general provisions of 'the Code of Obligations' concerning the formation, performance and termination of contracts also apply to other civil law matters. ${ }^{6}$ Therefore, the Swiss Code was amended by Federal Act on the Amendment of the Swiss Civil Code (Part Five: The Code of Obligations) No. 220.

The actual text of the Swiss Federal Code of Obligations (CO) concerning contracts and tort was adopted in 30/3/1911, then presented as a supplementary part of the Civil Code (Zivilgesetzbuch, voted December 10, 1907), both entered in force in $1 / 1 / 1912$. Its text is to a large extent based on its predecessor, the ancient CO as adopted in 1881 and in force since 1883. This text is worth being mentioned because it is in some details preferable to the actual version and also its creation preceded that of the German Civil Code (BGB) by almost two decades and necessarily influenced the latter. The influence demonstrated by the Swiss CO is remarkable in the Spanish speaking area and in the Far East. The influence of the Swiss CO is clearly predominant in the traditional Chinese Code, the Code of the Republic of South Korea and the Code of Thailand. Moreover, in 1926 under Kemal Atatürk, Turkey adopted the Swiss Civil Code including the CO without major modifications. The contract law of the CO is as in all areas of the continental civil law, based mainly on the tradition of Roman law. Mostly the German "doctrine of the Pandects" of the 19th century influences the Swiss CO, therefore the BGB is the next of kin to the Swiss CO. ${ }^{7}$

\footnotetext{
${ }^{1}$ Contract Law of the People's Republic of China of 1999, Article 17 and 18.

${ }^{2}$ Contract Law of the People's Republic of China of 1999, Article 19.

${ }^{3}$ Contract Law of the People's Republic of China of 1999, Article 20.

${ }^{4}$ Contract Law of the People's Republic of China of 1999, Article 23.

${ }^{5}$ Contract Law of the People's Republic of China of 1999, Article 23.

${ }^{6}$ Swiss Civil Code 1907, Article 7.

7 E Bucher, 'Law of Contract' in F Dessemontet and T Ansay (eds) Introduction to Swiss Law (3 ${ }^{\text {rd }}$ edn Kluwer Law Intl, Hague 2004) 103.
} 
Under Swiss CO, the conclusion of a contract requires a mutual expression of intent by the parties and the expression of intent may be express or implied ${ }^{1}$ so an offer, though oral, may be binding. Also, pursuant to the Swiss $\mathrm{CO}$, the intention of being bound by the offer is presumed. If the offeror does not express his intention to reserve his right to revoke the offer, it cannot be withdrawn. Nevertheless, some circumstances may show that a party does not intend to be bound. The sending out of price-lists, for example, is deemed to be not an offer but an invitation to make one. Moreover, The acceptance must be entirely consistent with the offer; a modification of conditions of the original offer is not an acceptance but is deemed to constitute a counter-offer. ${ }^{2}$ The prove for these rules is Article 7 of the Swiss CO, which provides that:

1. An offeror is not bound by his offer if he has made express declaration to that effect or such a reservation arises from the circumstances or from the particular nature of the transaction.

2. The sending of tariffs, price lists and the like does not constitute an offer.

3. By contrast, the display of merchandise with an indication of its price does generally constitute an offer. ${ }^{3}$

Pursuant to the Articles 3 and 4 of the Swiss CO, the duration of the binding effect may be fixed by the offeror at his free discretion. If no time limit has been fixed, an offer is open for a reasonable period of time, allowing the transmission of the acceptance under normal circumstances after a short time of reflection. An offer made viva voce to a present partner or by phone has no binding effect if the offeror does not expressly declare his or her intention to be bound for a certain period. The Article 3 states that:

1. A person who offers to enter into a contract with another person and sets a time limit for acceptance is bound by his offer until the time limit expires.

2. He is no longer bound if no acceptance has reached him on expiry of the time limit. ${ }^{4}$

And the Article 4 provides that:

1. Where an offer is made in the offeree's presence and no time limit for acceptance is set, it is no longer binding on the offeror unless the offeree accepts it immediately.

2. Contracts concluded by telephone are deemed to have been concluded in the parties' presence where they or their agents communicated in person. ${ }^{5}$

Moreover, the Swiss CO regulates the offeree's absence circumstances. It provides that where an offer is made in the offeree's absence and no time limit for acceptance is set, it remains binding on the offeror until such time as he might expect a reply sent duly and promptly to reach him. He may assume that his offer has been promptly received. Also, where an acceptance sent duly and promptly is late in reaching the offeror and he does not wish to be bound by his offer, he must immediately inform the offeree. ${ }^{6}$

Under certain circumstances explicit acceptance is not required; in such cases the addressee of the offer is bound to the contract if he does not expressly reject the offer. This applies to contracts that are exclusively beneficial to like donations to the donee or assignments to the assignee. ${ }^{7}$ The Article 6 of the Swiss CO holds that "[w]here the particular nature of the transaction or the circumstances are such that express acceptance cannot reasonably be expected, the contract is deemed to have been concluded if the offer is not rejected within a reasonable time." 8 Additionally, pursuant to Article 6(a) "[t]he sending of unsolicited goods does not constitute an offer. The recipient is not obliged to return or keep such goods. [Also,] [w] here unsolicited goods have obviously been sent in error, the recipient must inform the sender."

Under the provisions of Article 8 and 9 of the Swiss CO, an offer to the public in general is possible. The obligation of the offering person is not created by an explicit acceptance of the other party but by the performance required by the promise declared to the persons possibly interested. ${ }^{10}$ The Article 8 states that:

1. A person who publicly promises remuneration or a reward in exchange for the performance of an act must

\footnotetext{
${ }^{1}$ The Swiss Code of Obligation No. 220 of 1911, Article 1 (1 and 2).

${ }^{2}$ Bucher, op. cit., p. 110.

${ }^{3}$ The Swiss Code of Obligation No. 220 of 1911, Article 7 (1- 3).

${ }^{4}$ The Swiss Code of Obligation No. 220 of 1911, Article 3 (1and 2).

${ }^{5}$ The Swiss Code of Obligation No. 220 of 1911, Article 4 (1 and 2).

${ }^{6}$ The Swiss Code of Obligation No. 220 of 1911, Article 5 (1- 3).

${ }^{7}$ Bucher, loc. cit.

${ }^{8}$ The Swiss Code of Obligation No. 220 of 1911, Article 6.

${ }^{9}$ The Swiss Code of Obligation No. 220 of 1911, Article 6 (a) 1-3.

${ }^{10}$ Bucher, op. cit., p. 110 and 111.
} 
pay in accordance with his promise.

2. If he withdraws his promise before performance has been made, he must reimburse any person incurring expenditure in good faith on account of the promise up to the maximum amount promised unless he can prove that such person could not have provided the performance in question.

Also, Article 9 provides that:

1. An offer is deemed not to have been made if its withdrawal reaches the offeree before or at the same time as the offer itself or, where it arrives subsequently, if it is communicated to the offeree before he becomes aware of the offer.

2. The same applies to a withdrawal of an acceptance. ${ }^{2}$

Finally, under the Article 10 "[a] contract concluded in the parties' absence takes effect from the time acceptance is sent. Where express acceptance is not required, the contract takes effect from the time the offer is received. ${ }^{3}$

\section{Conclusion}

Contracts are indispensable tools of business and other human interactions. A contract is an agreement between two or more parties commit themselves to one or more others to give, to do, or not to do something that are enforced by law. To conclude a valid contract, a number of essential elements and requirements are necessary. The elements and requirements are different between common law and civil law systems. However, generally it can be said there must be agreement, intention to create a legally binding agreement, a price paid (not necessarily money), a legal capacity to enter a contract of your own free will, and legal consideration provided by each of parties. One of the main essential elements of contract in both civil law and common law systems is agreement (consent of the parties). An agreement is composed of two elements: offer and acceptance that one party made an offer, and the other party accepted this offer. Consequently, this study has a number of general findings, the most important of which are as follows:

In terms of common law system, this study has demonstrated that not all communications will be offers, and an offer is distinctive from other steps in the negotiation process such as declaration of intention and an invitation to offer. Also, this study has illustrated that sometimes confusion may arise when what would appear to be an offer is held by the law to be only an invitation to offer. In a wide variety of circumstances, courts have considered whether or not a communication was an offer or an invitation to offer. This issue arises particularly in advertisements, display of goods in shops, request for tenders and auctions. Moreover, this study has highlighted a number of circumstances in which an offer may be terminated, including death of offeror or offeree, lapse of time, revocation or withdrawal of offer, counter offer and rejection.

In terms of civil law system, the French, German, Iraqi, Swiss and China Civil Codes has been concentrated with regards to the offer. The study has explained that there was no specific article of the French Civil Code of 1804 that requires the existence of an offer and an acceptance. However, reform and modernisation of contract law in French has been taken. The section of the Civil Code on the law of contract was amended in 2016. The French Civil Code Reform regulates formation of contracts in details, especially the offer and acceptance. The reform has defined the offer and distinguished between offer and invitation to enter into negotiations. It also mentioned a number of circumstances in which the offer can be withdraw. The reform also provides several situations in which the offer lapse. Moreover, it regulates contracts that made by electronic means in details.

German Civil Code regulates the offer and mentions a number of offer termination and revocation circumstances. The German Code also regulates the death or incapacity to contract of the offeror and promise of a reward in details.

The study has further found that the Iraqi Civil Code, in contrary to the law of many countries of civil law systems regulates both offer and acceptance together in a number of articles. According to the law, offer and acceptance will be in the past tense and may be in the future tense or in the form of an order. The Iraqi Civil Law distinguishes the offer from the invitation to offer but not very successfully. The law states that the display of goods with a price shown on them is deemed to be an offer; but, publishing, advertising and listing prices of current dealings and

\footnotetext{
${ }^{1}$ The Swiss Code of Obligation No. 220 of 1911, Article 8 (1and 2).

${ }^{2}$ The Swiss Code of Obligation No. 220 of 1911, Article 9 (1and 2).

${ }^{3}$ The Swiss Code of Obligation No. 220 of 1911, Article 10.
} 
every other statement concerning offers or calls addressed to the public or to individuals in case of doubt will be deemed an invitation to negotiate. It also mentions a number of offer termination circumstances and regulates offer in auctions.

The Contract Law of China defines the offer and distinguishes the offer from the invitation to offer. It states that a delivered price list, announcement of auction, call for tender, prospectus, or commercial advertisement, etc. are invitations to offer, but a commercial advertisement is deemed an offer if its contents meet the requirements of an offer. The law also regulates withdrawal of offer, revocation circumstances and extinguishment of offer.

Finally, this study has illustrated that under the Swiss CO, the intention of being bound by the offer is presumed. If the offeror does not express his intention to reserve his right to revoke the offer, it cannot be withdrawn. Swiss $\mathrm{CO}$ has mentioned a number of circumstances as invitation to offer, for example, the sending out of price-lists. By contrast, the display of merchandise with an indication of its price does generally constitute an offer. Under the Swiss CO, the duration of the binding effect may be fixed by the offeror at his free discretion. If no time limit has been fixed, an offer is open for a reasonable period of time. Moreover, the code regulates the offeree's absence circumstances and withdrawal of offer.

\section{References}

Books:

Elliott, C and Quinn, F, Contract Law (7th edn Pearson Education Limited, Harlow 2009).

Longchamps, D and Wright, BH, Canadian Hospitality Law: Liabilities and Risks ( ${ }^{\text {rd }}$ edn Nelson Education Limited, Toronto 2006).

MacMillan, C and Stone, R, Elements of the Law of Contract (University of London International Programmes Publication Office, London 2012).

Mckendrick, E, Contract Law (12 ${ }^{\text {th }}$ edn Palgrave, London 2017).

McKendrick, E, Contract Law ( $4^{\text {th }}$ edn Palgrave, London 2000).

Uher, T E and Davenport, P, Fundamentals of Building Contract Management ( $2^{\text {nd }}$ edn UNSW Press, Sydney 2009).

Chapter from Edited Books:

Bucher, E, 'Law of Contract' in F Dessemontet and T Ansay (eds) Introduction to Swiss Law (3 ${ }^{\text {rd }}$ edn Kluwer Law Intl, Hague 2004).

\section{Journal Articles:}

CMoss, G, 'International Contracts between Common Law and Civil Law: Is Non-state Law to Be Preferred? The Difficulty of Interpreting Legal Standards Such as Good Faith' (2007) 7 (1) Global Jurist 1-38.

Ferrari, F, 'Formation of Contracts in South American Legal Systems' (1994) 16 Loy. L.A. Int'l \& Comp. L. Rev. $629-659$

Pejovic, C, 'Civil Law and Common Law: Two Different Paths Leading to the Same Goal' (2001) 32 VUWLR, 817-842.

\section{Electronic Resources:}

Cauuet, $\mathrm{C}$ and Dubos, G, The reform of the French civil code and of contract law: consent to the contract $<$ http://www.loyerabello.fr/en/the-reform-of-the-french-civil-code-and-of-contract-law-consent-to-thecontract/> accessed 27August 2020.

Doyles, Harvela Investment Ltd v royal Trust Co of Canada Ltd $<$ https://doylesconstructionlawyers.com/casewatch-list/harvela-investments-v-royal-trust-company-ofcanada/> accessed 20 August 2020.

Goyal, K, Harris vs Nickerson By Jayant Sarkar from Lloyd Law College <

http://educoncours.com/2017/08/18/harris-vs-nickerson-jayant-sarkar-lloyd-law-college/> accessed

17August 2020.

Lawyers from Allen \& Overy, At a Glance Guide to Basic Principles of English Contract Law < http://www.a4id.org/wp-content/uploads/2016/10/A4ID-english-contract-law-at-a-glance.pdf $>$ accessed 13 August 2020.

Norton Rose Fulbright, Reform of the French Civil Code on contract law and the general regime and proof of obligations $<$ http://www.nortonrosefulbright.com/knowledge/publications/143164/reform-of-the-french- 
civil-code-on-contract-law-and-the-general-regime-and-proof-of-obligations\#autofootnote2 $>$ accessed 25 August 2020.

Ohly, Introduction to English Law < http://www.zivilrecht8.uni-bayreuth.de/de/download/DownloadArchiv/English Law WS0809/EL 22 LN.pdf $>$ accessed 15August 2020.

Rowan, S, 'The New French Law of Contract' International \& Comparative Law Quarterly (2017) < http://eprints.1se.ac.uk/75815/1/Rowan New\%20French\%20law 2017.pdf> accessed 25 August 2020.

The Editors of Encyclopædia Britannica, 'Napoleonic Code' $<$ https://www.britannica.com/topic/Napoleonic$\underline{\text { Code }}>$ accessed 25 August 2020.

Uk Web Hosting, Contractual Agreement - Offer and Acceptance < http://www.e-lawresources.co.uk/Offerand-acceptance.php/index.php $>$ accessed 20 August 2020.

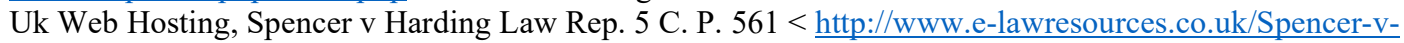

Harding.php $>$ accessed 20 August 2020.

\section{Table of Statutes}

Contract Law of the People's Republic of China of 1999.

French Civil Code of 1804 (Amendment).

German Civil Code (BGB) of 1896.

Indian Contract Act 1872.

Iraqi Civil Code (Amendment) No.40 of 1951.

Swiss Civil Code 1907.

The Swiss Code of Obligation No. 220 of 1911.

\section{Table of International Conventions}

The Vienna Convention on Contracts for the International Sale of Goods (CISG).

\section{Table of Cases}

Barry v Davies [2000] 1 WLR 1962

Blackpool and Fylde Aero Club Ltd v Blackpool Borough Council [1990] 3 All ER 25, [1990] 1 WLR 1195

Byrne \& Co v Leon Van Tienhoven [1880] 5 CPD 344

Carlill v Carbolic Smoke Ball Co. [1893] 1 QB 256

Dickinson v Dodds [1876] 2 Ch. D

Fisher v Bell [1961] 1 QB 394

Fitch $v$ Snedaker [1868] 38 NY 248

Gibson v Manchester City Council [1979] UKHL 6, [1979] 1 WLR 294

Grainger \& Sons v Gough [1896] AC 325

Harris v Nickerson [1873] 1 LR 8 QB 286

Partridge v Crittenden [1968] 2 ALL ER 421

Pharmaceutical Society of Great Britain v Boots Cash Chemists (Southern) Ltd [1953] 1 QB 401

$R v$ Clarke [1927], 40 CLR 227

Ramsgate Victoria Hotel v Montefiore [1866] LR 1 Ex 109

Routledge v Grant [1828] 130 ER 920

Spencer $v$ Harding Law Rep. 5 C. P. 561

Storer v Manchester City Council [1974] 3 ALL ER 824.

The Brimnes [1975] QB 929

Thornton $v$ Shoe Lane Parking [1971] 2 WLR 585 Court of Appeal 